\title{
PROBLEMS AND NORMATIVE EVALUATION OF BOND-STRENGTH TESTS FOR COATED REINFORCEMENT AND CONCRETE
}

\author{
PROBLEMI IN NORMATIVNA OCENA PREIZKUSOV TRDNOSTI \\ VEZI MED ARMATURO S PREKRITJEM IN BETONOM
}

\author{
Petr Pokorný ${ }^{1}$, Milan Kouřil ${ }^{1}$, Jan Stoulil ${ }^{1}$, Petr Bouška ${ }^{2}$, Pavel Simon ${ }^{3}$, \\ Pavel Juránek ${ }^{4}$ \\ ${ }^{1}$ Institute of Chemical Technology in Prague, Department of Metals and Corrosion Engineering, Technická 5, 16628 Prague 6, Czech \\ Republic \\ ${ }^{2}$ Czech Technical University in Prague, Klokner Institute, Šolínova 7, 16608 Prague 6, Czech Republic \\ 3Ing. Vladimír Fišer, Mlýnská 68, 60200 Brno, Czech Republic \\ ${ }^{4}$ Technical and Test Institute for Constructions Prague - Brno Branch, Hněvkovského 77, 61700 Brno, Czech Republic \\ Pokornyt@vscht.cz
}

Prejem rokopisa - received: 2014-09-13; sprejem za objavo - accepted for publication: 2015-01-05

doi:10.17222/mit.2014.227

\begin{abstract}
This paper focuses on the problems of the bond-strength between concrete and reinforcement and defines the basic factors affecting the quality of the bond. Two types of coated concrete reinforcement (the zinc- and epoxy-coated) and methods of testing their bond-strength with concrete are described. The goal of this work is to generalize the results of the bond-strength tests so that they would consider only the influence of the corrosion of the zinc-coated reinforcement in fresh concrete or, in the case of the epoxy-coated reinforcement, its probable constriction during the testing. Based on described standards, it is recommended to use the pull-out test to obtain these generalized results: two Czech standards (Bond-strength test of the reinforcement cast in prisms, Beam-strength test of the reinforcement in cubes) and a RILEM recommendation.

Keywords: concrete, corrosion of concrete reinforcement, bond-strength, bond-strength tests, hot-dip galvanized reinforcement,
\end{abstract} epoxy-coated reinforcement, standards

Članek obravnava probleme trdnosti vezi med betonom in armaturo ter določa osnovne faktorje, ki vplivajo na kvaliteto vezi. Opisani sta dve vrsti prekritja armature (prekritje s cinkom in prekritje z epoksi smolo) in kako se preizkusi njihova trdnost vezi z betonom. Cilj tega dela je bil dobiti rezultate preizkusov trdnosti vezi, ki bi upoštevali samo vpliv korozije pri armaturi, pokriti $\mathrm{s}$ cinkom $\mathrm{v}$ svežem betonu ali, $\mathrm{v}$ primeru armature, pokrite $\mathrm{z}$ epoksi smolo, na njeno zoženje med preizkusom. Na podlagi opisanih standardov se priporoča preizkus izpuljenja, da se dobi posplošene rezultate: dva češka standarda (Preizkus trdnosti vezi betona ulitega v prizme, Preizkus trdnosti betonske kocke) in RILEM-priporočilo.

Ključne besede: beton, korozija armature v betonu, trdnost vezi, preizkusi trdnosti vezi, vroče cinkana armatura, armatura z nanosom epoksi smole, standardi

\section{INTRODUCTION}

The durability of reinforced-concrete structures is always limited by the corrosion of carbon-steel reinforcement. The volume of corrosion products is significantly larger (2-6-times) than the volume of the original non-corroded reinforcements, thus creating a stress leading to the formation of cracks in the initial stages of concrete solidification, eventually resulting in a disintegration of the concrete cover. The initiation of reinforcement corrosion corresponds to the carbonation of the concrete cover by $\mathrm{CO}_{2}$ (the carbon steel becomes active due to a $\mathrm{pH}$ reduction of the alkaline pore solution) and/or, more frequently, a local attack by penetrating chlorides (deicing salt, seawater). A disintegration of the concrete cover propagates the attack to the other parts of the reinforcement. A reduction of the reinforcement diameter by the corrosion poses a significant threat to the static function of the construction. The whole corroded reinforcement often needs to be replaced at great expenses to repair the construction..$^{1-3}$
The prolongation of the longevity of concrete reinforcement basically falls into two categories. The first one involves a change in the concrete properties to increase the compactness of the concrete cover (the concretes with a low water-cement ratio, a better concrete densification, final application of various concrete plasticizers or other changes to the concrete composition). Special cements with a suitable ash substituting the cement provide another way to increase the compactness - these concretes can have higher mechanical properties, a lower inherited porosity and, therefore, lower penetration of water, oxygen and corrosion stimulators. ${ }^{4} \mathrm{~A}$ surface modification with a barrier effect slowing down the penetration of carbon dioxide and chlorides such as paint or an organosilane surface modification (the surface becomes hydrophobic) are also not negligible.

The second category focuses on the reinforcement. Its examples are corrosion inhibitors, a cathodic protection, the coating of the reinforcement or application of a 
reinforcement from another material (stainless steel, composite reinforcement) ${ }^{5,6}$

A significant advantage of stainless steel, compared to carbon steel, is its high resistance to a low-pH pore solution. Its resistance to chloride-containing environment depends on the composition of the steel - certain types are prone to a localized corrosion attack. Nevertheless, the critical chloride concentration causing the activation of steel can be up to $15 \times$ higher than that for carbon steel. ${ }^{7,8}$ Similarly to carbon steel, the resistance of stainless steel is limited by the state of its surface. The scales formed during hot-working or welding have a strong detrimental effect on its corrosion resistance. It was discovered that even an increase in the $\mathrm{pH}$ from 12.5 to 13.5 improves the corrosion resistance less than the removal of the surface. ${ }^{9}$

The surface finish of a steel reinforcement can enhance the corrosion resistance of the reinforcement in a concrete environment while the core of the reinforcement maintains all of its necessary mechanical properties (weldability, tensile and compressive strengths, fatigue strength, etc.). Currently, the feasibility of hot-dip galvanized coating and powder-plastic coating is being discussed. However, these kinds of reinforcement protection cannot be employed until the bond between the concrete and these new surface-modified reinforcements has been thoroughly studied. ${ }^{10}$

\section{CONCRETE-REINFORCEMENT BOND- STRENGTH}

A perfect and permanent bond between all steel-reinforcement components and concrete is the basic requirement for the static cooperation of both materials. The quality of the bond depends on their reciprocal cohesion, the bond durability corresponds to the similarity of their thermal-expansion coefficients and the corrosion resistance of the reinforcement material. Different thermalexpansion coefficients cause both materials to behave differently during temperature changes, thus negatively affecting their bond. ${ }^{11}$

The concrete-reinforcement bond is generally a combination of all the factors affecting the movement of reinforcement during a transformation of a concrete structures reinforced by steel. It is thus important for the reinforcement components to change similarly to the concrete during loading and prevent their movement. ${ }^{11,12}$

The total bond-strength $\left(B_{\mathrm{s}}\right)$ between concrete and its reinforcement is a combination of three factors from the bond-strength formula: adhesion factor $f_{\text {ad }}$ which includes the effect of the small surface defects of the reinforcement, friction factor $f_{\mathrm{f}}$ which takes into account small surface unevenness of the reinforcement causing friction and, finally, mechanical bonding factor $f_{\text {mech }}$ which includes the effect of the surface geometry (ribs, imprints, warping, etc.). The bond-strength formula is written as Equation (1): ${ }^{13}$

$$
B_{\mathrm{s}}=f_{\mathrm{ad}}+f_{\mathrm{f}}+f_{\text {mech }}
$$

The factors mentioned above do not have even effects on the bond-strength. The mechanical bonding factor has the greatest effect on the bond-strength. The reason for this is the fact the above factors also necessarily include the effects of the mechanical properties of concrete - its local hardness (included in the friction factor) and compressive strength (included in the mechanical bonding factor). The adhesion factor is strongly affected by the concrete porosity - a high porosity decreases the effect of the physicochemical interactions at the interface which are always short-range. The bond is formed by hydrating concrete penetrating the reinforcement-surface defects, creating a mechanical bond. The mechanical bond becomes strengthened, to some extent, during the concrete's aging due to its constriction around the reinforcement. ${ }^{12,13}$

The tensile forces of the reinforcement must be transferred to the concrete in the less-stressed areas and the reinforcement must be well bound. Bond length $l_{\mathrm{b}}$ is defined as the length of the reinforcement inside the concrete necessary for the reinforcement to crack (during pulling) instead of being torn out of the concrete. Tangential stress $\left(\tau_{\mathrm{b}}\right)$ occurs on the surface of the reinforcement - the force $(F)$ is distributed unevenly along the reinforcement; for the sake of simplicity, the average value is typically used in structures design. This value is given by Equation (2) ( $u$ is the rod diameter, $l_{\mathrm{b}}$ is the length of the rod set in concrete):

$$
\tau_{\mathrm{b}}=\frac{F}{u l_{\mathrm{b}}}
$$

Considering the bond-strength, we can define the limit bond length according to Equation (3) $\left(f_{\mathrm{yk}}\right.$ is the characteristic yield strength of the reinforcement rod, $\Phi$ is the nominal diameter of the reinforcement rod, $f_{b d}$ is the design value of the ultimate bond stress):

$$
l_{\mathrm{b}}=\frac{\Phi}{4} \frac{f_{\mathrm{yk}}}{f_{\mathrm{bd}}}
$$

The key to correctly calculate the sufficient bond length is the reinforcement-concrete bond-strength. In mathematical models, the bond-strength is represented by the design value of the ultimate bond stress $f_{\text {bd }}$ which can be calculated, for ribbed reinforcements, from Equation (4) $\left(\eta_{1}\right.$ is the factor including the aging conditions and the position of the reinforcement rod during the casting of concrete, $\eta_{2}$ is the factor including the normative diameter of the reinforcement $\operatorname{rod}, f_{\text {ctd }}$ is the design tensile strength that should not exceed the value set for the C60/75 concrete strength class): ${ }^{12}$

$$
f_{\text {bd }}=2.25 \eta_{1} \eta_{2} f_{\text {ctd }}
$$

When assessing the effect of concrete on the strength of its bond with the reinforcement, it is generally important for the cement content in the concrete to be high, since the hydrating cement must adhere well to the rein- 


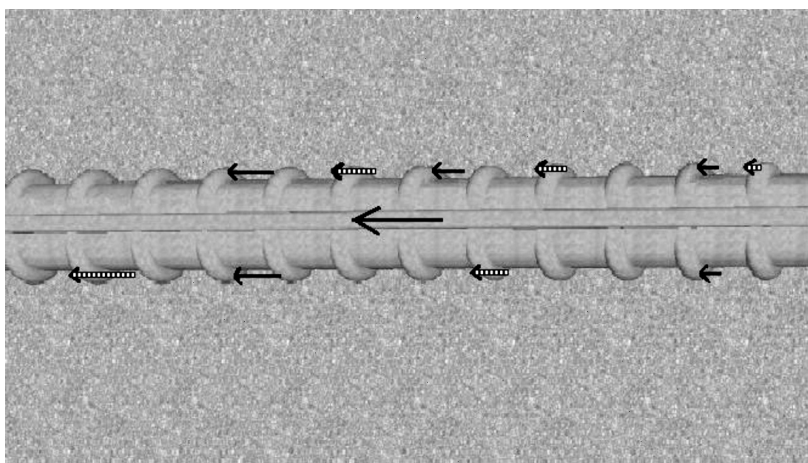

Figure 1: Idealized effect (compressive - dotted vectors and tensile full length vectors) of ribbed rod reinforcement in the beginning stages of loading (black vector shows the strain direction)

Slika 1: Idealiziran vpliv (tlačni - črtkasti vektorji in natezni polnočrtni vektorji) rebraste palice armature $v$ začetnem stadiju obremenitve (črni vektor kaže smer deformacije)

forcement rods. Concrete must also be well compacted. Single rods must be covered by concrete on all sides and the minimum cover thickness must be maintained. As shown above in Equation (4), the position of the reinforcement in concrete also has an effect on its final strength. The horizontal rods closer to the bottom have a better bond-strength than those closer to the top surface. The reason for this is a gradual settlement of the concrete. This is more significant for the concretes with a higher mixing-water content.

The surface of a reinforcement plays a major role. It needs to be rough and clean, suitably degreased and rust-free. When a load is applied to the reinforcement, the ribbings stress the concrete in their vicinity, creating a transverse tensile stress, eventually causing the concrete to crack behind the ribbings, relative to the trajectory of the applied load (Figures 1 and 2). A higher loading causes the shear strength of concrete to be exceeded and the reinforcement rod to "cut out" of the concrete (Figure 3). ${ }^{12,14}$

The bond-strength of concrete is mainly determined by the mechanical bonding factor; for the ribbed bar

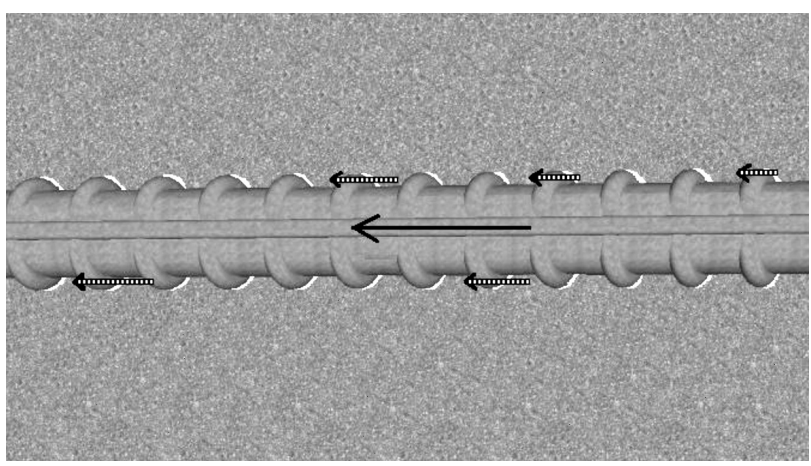

Figure 2: Idealized model of reinforcement movement (black vector), when the bond is broken (dotted vectors show the compressive forces on the concrete caused by the ribs)

Slika 2: Idealiziran model premikanja armature (črni vektor), ko se povezava prekine (črtkasti vektorji kažejo tlačne sile na beton, ki jih povzročijo rebra)

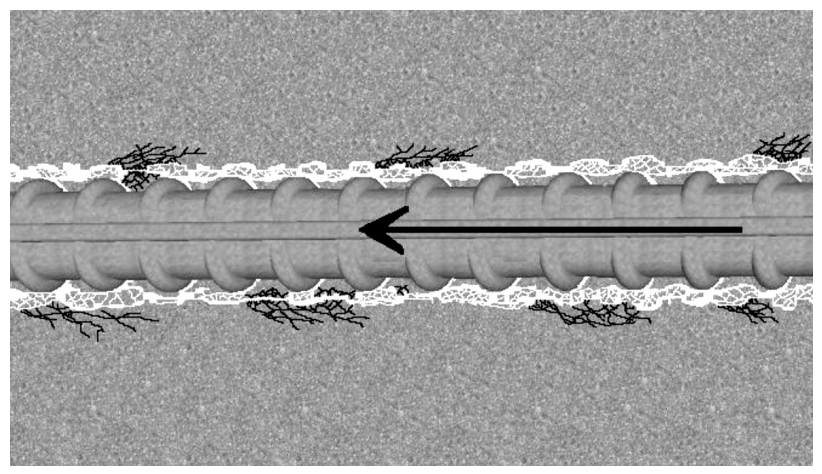

Figure 3: Idealized model depicting cutting-out of the ribbed reinforcement right before its pull-off of concrete. Longitudinal crack spreads through concrete closely above the ribs.

Slika 3: Idealiziran model prikazuje izpuljenje rebraste armature tik pred njenim izpuljenjem iz betona. Vzdolžne razpoke se širijo skozi beton, tik nad rebri.

reinforcement, the bond-strength depends on the relative rib area $f_{\mathrm{R}}$ that can be calculated from the rib geometry using Equation (5), while the area of a single rib $F_{\mathrm{R}}$ needs to be calculated using Equation (6) ( $d$ is the nominal reinforcement-bar diameter, $c$ is the distance between the centers of two adjacent ribs, $\beta$ is the angle of the rib inclination, $n$ is the number of crosswise rows on the rod perimeter, $m$ is the number of differently angled ribs in a column, $q$ is the number of crosswise longitudinal ribs for cold-bent rods, $P$ is the number of threads of the rib spiral, $a_{\mathrm{k}}{ }^{\prime}$ is the average height of longitudinal ribs, $a_{\mathrm{S}, i}$ is the average height of the $i$ parts of the ribs divided in $p$ parts with a $\Delta l$ length, Figures 4 and 5). The second addend applies only to cold-bent rods and is neglected if it exceeds $30 \%$ of the total value of $f_{\mathrm{R}}: 15,16$

$$
\begin{gathered}
f_{\mathrm{R}}=\frac{1}{\pi d} \sum_{i=1}^{n} \frac{(1 / m) \sum_{j=1}^{m} F_{\mathrm{R}, i, j} \sin \beta_{i, j}}{\mathrm{c}_{\mathrm{i}}}+\frac{1}{P} \sum_{k=1}^{q} a^{\prime}{ }_{k} \\
F_{\mathrm{R}}=\sum_{i=1}^{p}\left(a_{\mathrm{S}, i} \Delta l\right)
\end{gathered}
$$

The desired values of the relative rib surface and their shapes are given in the design standards. The minimum

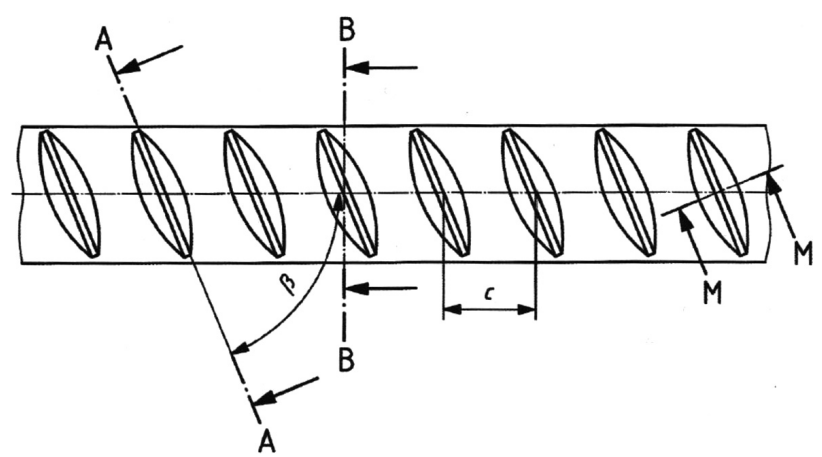

Figure 4: Detail of a rib configuration for a calculation of the relative rib surface $f_{\mathrm{R}}$

Slika 4: Podrobnosti konfiguracije reber za izračun relativne površine reber $f_{\mathrm{R}}$ 


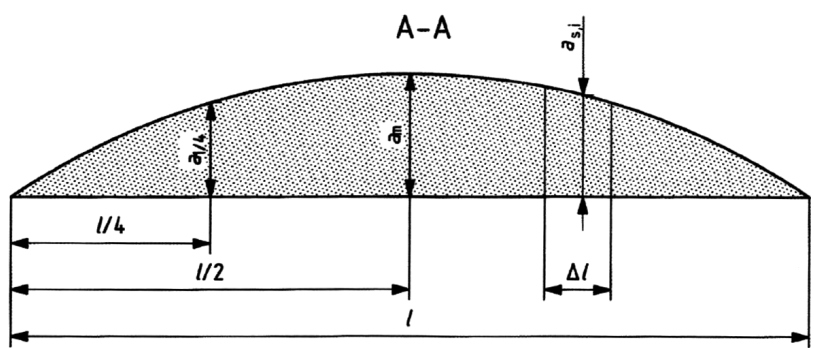

Figure 5: Cross-section of a rib for a calculation of the rib surface $F_{\mathrm{R}}$ Slika 5: Prerez rebra za izračun površine $F_{\mathrm{R}}$ rebra

relative surface $f_{\mathrm{R}, \min }$, related to the nominative bar diameter, is usually known. The nominal evaluation of the minimum relative rod surface is shown in Table $\mathbf{1 .}^{15}$

Table 1: Evaluation of minimum relative surface of ribs to ensure a good strength of the bond with bars, foils and also welded nets ${ }^{15}$

Tabela 1: Ocena minimalnih površin reber za zagotovitev dobre trdnosti vezave $\mathrm{s}$ palicami, folijami in tudi $\mathrm{z}$ varjenimi mrežami ${ }^{15}$

\begin{tabular}{|c|c|}
\hline $\begin{array}{c}\text { nominal diameter of } \\
\text { reinforcement } d_{\mathrm{s}} / \mathrm{mm}\end{array}$ & $\begin{array}{c}\text { minimum relative rib surface } \\
\left(f_{\mathrm{R}, \mathrm{min}}\right)\end{array}$ \\
\hline $5-6$ & 0.035 \\
\hline $6.5-2$ & 0.040 \\
\hline$>12$ & 0.056 \\
\hline
\end{tabular}

\section{PROBLEMS OF CONCRETE-REINFORCEMENT BOND-STRENGTH TESTS}

The available standards recommend two experimental set-ups to determine the reinforcement-concrete bond-strength. The first of them is based on pulling out a steel-bar reinforcement set from the concrete. The second set-up is basically a 4-point beaming test - a determination of the bond-strength for bent concrete girders, a girder test, a beam test, etc.

Both methods produce quite different results which make an objective assessment of the concrete-reinforcement bond-strength difficult. Nonetheless, comparing the data obtained with a repeated measurement using the same method is also somewhat complicated. For both methods, the non-objectivity of the measurements come from the standards themselves. In the case of the pull-out test of a reinforcement with a bonding component (indentation, rib, corrugation), the concrete is disintegrated during the test (Figure 3). The results are, therefore, strongly dependent on the strength of the concrete. Also, the results of "the beam test" cannot be used to make a general statement about the bond-strength - the forced bending momentum creates a compressive stress in the upper part of the beam and a tensile stress in the lower part. Any reasonably changed experimental set-up still cannot provide us with the data disregarding the mechanical properties of concrete.

These influences can be ignored using a modified pull-out test with a smooth-surface reinforcement. However, the reinforcement must be perfectly aligned with the central axis of the fixed concrete sample so that there is no compressive stress. The data from these bondstrength tests for concrete and reinforcement cannot be used to make general assumptions about the real bondstrength since they are also influenced by many other factors. On the other hand, the results of a smooth reinforcement-concrete bond-strength test are of no practical use since the bond is primarily facilitated by the bonding components which are considered in the static calculations. ${ }^{15,17}$

\subsection{Bond-strength of a coated reinforcement}

Coating provides the reinforcement with a surface barrier which increases the time until the surface activation of the steel. A supplementary reinforcement coating can thus be used to prolong the longevity of iron-concrete constructions. However, the strength of the bond between the coating and the concrete must be correctly evaluated. A reduced coated reinforcement-concrete bond-strength, even on a scale of percent units, can make its practical application much more difficult. The reason for this is the concern about the static reliability, especially in the applications with high requirements - constructions with very high load-bearing capacities, dynamically stressed constructions. A reduced bond-strength can be solved by increasing the bond length or adding bonding profiles. A less effective alternative to this is a surface modification of the reinforcement (increasing the surface area of the bonding elements, i.e., ribs, indentations, corrugations, etc.). Increasing the bond length increases the cost of the construction; the coating requires additional concrete-reinforcement bond-strength tests to be performed (using the reinforcement with a modified surface). Two surface modifications are discussed: the hot-dip galvanized coating and the epoxy coating. ${ }^{15}$

A comparison of the bond-strength results between the coated and non-coated reinforcements of the same surface geometry must be done according to the standardized tests. A correct interpretation of the data is also of great importance. The bond-strength must also be measured when the reinforcement surface geometry, the concrete's chemical composition and other factors altering the bonding interaction are changed.

\subsubsection{Hot-dip galvanized reinforcement}

The suitability of a hot-dip galvanized (zinc) coating for a concrete steel reinforcement is still arguable. This modification provably has a positive effect on the resistance to chlorides and also on the resistance to carbonated concrete. ${ }^{2,18}$ However, zinc actively corrodes in fresh concrete (alkaline, $\mathrm{pH}$ often exceeds 13.0) producing hydrogen. Hydrogen increases the porosity of the concrete and reduces the adhesion factor, thus also reducing the total bond-strength. After the zinc coating actively corrodes in fresh concrete, the remaining coating does not always exhibit sufficient quality. ${ }^{17,19}$ Other authors verified the initial reduction of the 


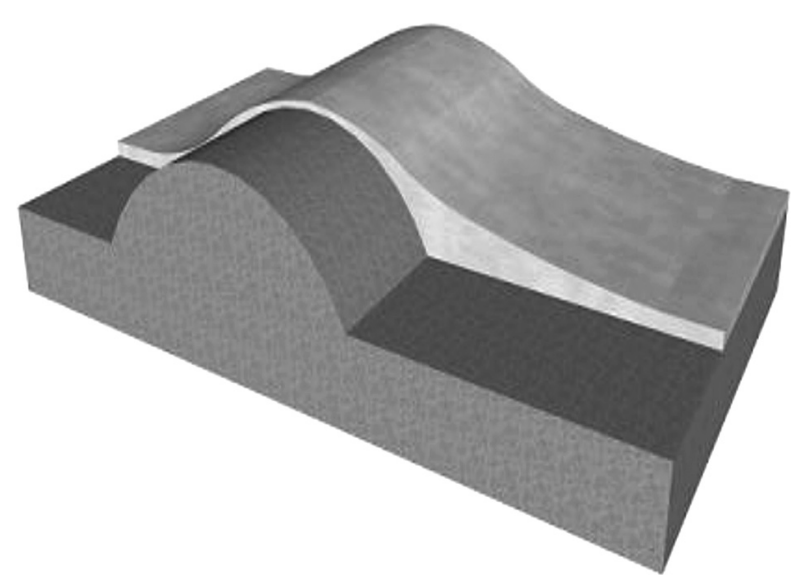

Figure 6: Model comparing the geometries of ribbed reinforcement with and without zinc coating

Slika 6: Model primerjave geometrije rebraste armature z nanosom cinka in brez njega

bond-strength; however, this is later compensated by zinc corrosion products $\left(\mathrm{Zn}(\mathrm{OH})_{2}\right)$ resulting from the concrete carbonation and filling in the pores. ${ }^{20-22}$

Another group of authors claim that a zinc-coated reinforcement easily becomes passivated in an environment with a $\mathrm{pH}$ value of 13.3 by forming non-soluble $\mathrm{Ca}\left[\mathrm{Zn}(\mathrm{OH})_{3}\right]_{2} \cdot 2 \mathrm{H}_{2} \mathrm{O}$; sulphate anions also have a positive effect on passivation. ${ }^{23-29}$ Another phenomenon - apart from the negative effect of zinc on the corrosion resistance of a reinforcement - a detrimental effect of zinc during the concrete hardening also needs to be mentioned. It was proven that zincates slow down the hardening of concrete and, with regard to the water content in concrete, they can extremely deteriorate the mechanical properties of concrete. ${ }^{30-32}$ Poor results for a zinc-coated ribbed reinforcement are sometimes explained with the smoothening of the surface by the zinc coating itself. A lower bond-strength corresponds to a lower relative rib surface $f_{\mathrm{R}}$, thus reducing the factor of mechanical bonding in the bond-strength equation $B_{\mathrm{s}}$. According to these authors, hot-dip zinc coating can result in the formation of an uneven coating - thicker at one heel of a rib (depending on how the rod was removed from the zinc bath) and very thin at the top of the rib (Figures 6 and 7). ${ }^{13}$ Others observed a reduced bond-strength for the hot-dip galvanized reinforcement even after a 28-day curing of the concrete..$^{33,34}$

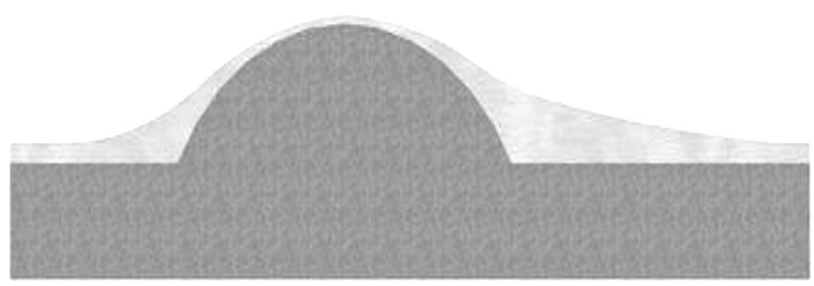

Figure 7: Cross-section model comparing the heights of the rib of non-coated and coated ribbed reinforcement from Figure 6

Slika 7: Model prereza, ki primerja višino rebra pri rebrasti armaturi z nanosom in brez njega s slike 6

\subsubsection{Epoxy-coated reinforcement}

The main problem of this type of coating is its mechanical resistance - it is very fragile and its manipulation is therefore problematic. Coating defects are formed during the bending, being set in the concrete, and often also during its fabrication. Another disadvantage is the necessity of welding prior to coating. A coated reinforcement can be linked only by sockets. ${ }^{8}$ The cracking of a coated reinforcement stored at a temperature below $10{ }^{\circ} \mathrm{C}$ was also observed. ${ }^{35}$ Corrosion products of steel forming on the surface of a reinforcement can also damage the epoxy coating. ${ }^{36}$ A perfect compact coating can prolong the longevity of concrete-steel constructions, but the problem lies in the strength of its bond with the concrete. Experts agree that an epoxy-coated reinforcement has a decreased strength of the bond with the concrete (sometimes even by 20-25\%). The recognized reasons for this include the concrete not adhering well to the reinforcement and creating only a small number of physico-chemical interactions, the smoothening of the ribs done in the way similar to the one used for the zinccoated reinforcement, or an elastic deformation of the epoxy coating during the loading. Epoxy-coated reinforcements usually have higher bond lengths and other anchoring modifications. ${ }^{37-40}$

\section{DETAILED DESCRIPTION AND CHARACTERIZATION OF THE STANDARDS}

The following text sums up the standards and recommendations for the arrangement, conditions and evaluation of bond-strength tests ( $\check{C} \mathrm{SN}$ standards, RILEM recommendations).

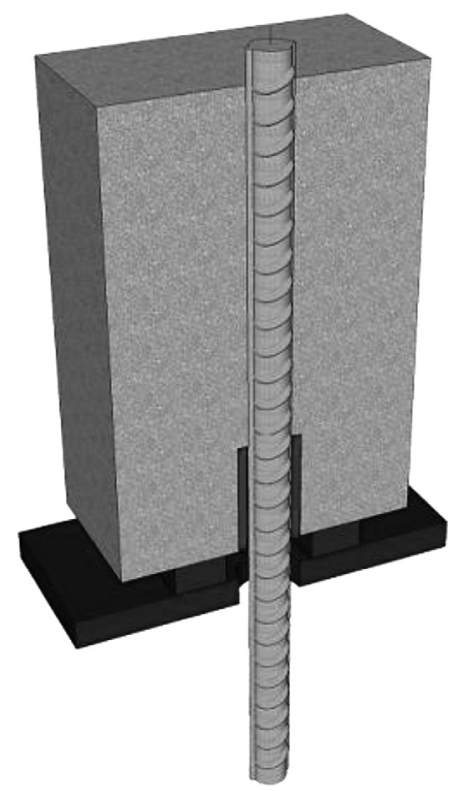

Figure 8: Schematics of the pull-out-test experimental set-up (concrete prism)

Slika 8: Shematski prikaz preizkusa izpuljenja (betonska prizma) 


\section{1 ČSN 731328 (determination of the concrete-rein- forcement bond-strength $)^{41}$}

This standard is the basic regulation for evaluating the bond-strength of the concrete with the components described above. It deals with both dense and aggregate concrete - the aggregate can be both dense and porous. The standard does not evaluate the effect of the reinforcement surface on the bond-strength. In this standard, the bond-strength is defined as the shear strength of the concrete (in the shear strength $\tau_{\mathrm{m}}[\mathrm{MPa}], \tau_{\mathrm{m}}=P_{\mathrm{m}} /(a \cdot o)$, $a$ is the bond length, $o$ is the diameter of the reinforcement) when the pull-out of the reinforcement from the concrete is $0.001 \mathrm{~mm}$ to $0.002 \mathrm{~mm}$. The bond-strength is thus defined as the shear strength on the tensile-stressed bar perimeter - this value is defined during the projecting of iron-concrete constructions.

\subsubsection{Determination of the steel-concrete bond-strength for a bar-shaped reinforcement}

Prior to the test, three cubic samples with $20 \mathrm{~cm}$ or $15 \mathrm{~cm}$ edge diameters, from the same concrete (i.e., an identical production and treatment procedure), are manufactured for the concrete-cube strength test. For the bond-strength test, bars of precise dimensions are manufactured using a reinforcement bar. To ensure that this bar is right in the axis of the concrete sample, it is inserted in a tube placed in the bottom part. The fresh concrete must be prevented from entering the tube. The bond length is the length of the concrete sample reduced by the length of the anchoring tube. The result is the arithmetic average value from three measurements (three parallel samples of one reinforcement type) of the bondstrength measured after 28 days of curing. The results that differ by more than $20 \%$ from the average are discarded (Figure 8).

\subsubsection{Strength of the bond between the steel and concrete in beam-stressed girders}

Similarly to the previous case, it is recommended to verify the concrete-cube strength prior to the test. Rectangular cross-section girders are used for this sample. Their dimensions are chosen to correspond to the bond lengths of the reinforcements (Figure 9). The test rein-

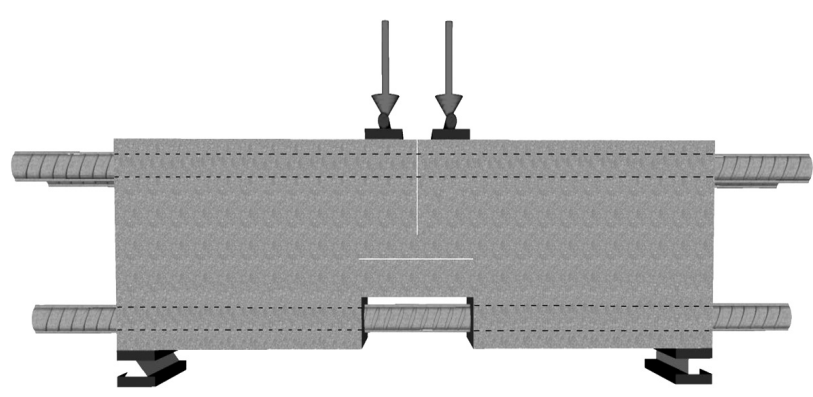

Figure 9: Schematics of reinforced girder prepared for a beam test with arrows showing the applied force

Slika 9: Shematski prikaz ojačanega nosilca, pripravljenega za upogibni preizkus, puščici kažeta uporabljeno silo

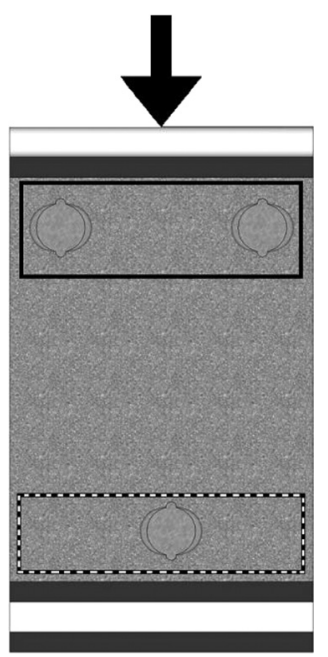

Figure 10: Cross-section of the beam-test girder sample: compressed part (full line) and tensile-stressed part (dotted line)

Slika 10: Prerez nosilca za upogibni preizkus: tlačni del (polna črta) in natezno obremenjen del (črtkasta črta)

forcement is set in the pulled part of the girder (i.e., the part where the bending stress is manifested as the tensile stress); the sample also contains two auxiliary reinforcement bars in the compressed part. The girder is also equipped with two closed clamps in the middle of the tensile-stressed part with an artificial interstice reaching about half of the girder's height. There is also a very narrow interstice in the tensile-stressed part. Both interstices are present to provide a suitable load-distribution path. The bottom reinforcement is also partially exposed so that its deformation can be easily measured.

The reinforcements in this set-up are set in tubes to ensure a precise settlement in the concrete and prevent their deformation during the loading. There are steel spikes in the heads of the girder with deviation meters for measuring the movement of the reinforcement towards the inner part of the girder (Figure 10). The test takes place after $28 \mathrm{~d}$ of curing the concrete in specified conditions. During the test, several parameters are measured: the bending of the girder, which is measured in the middle part with an accuracy of $0.001 \mathrm{~mm}$, the deformation of the middle part of the bottom reinforcement (an accuracy of $0.0001 \mathrm{~mm}$ ), the shift of the reinforcement towards the inner part of the girder (an accuracy of 0.001 $\mathrm{mm}$ ) and the pulling strength during the first decrease of the bond-strength (a reinforcement shift of $0.002 \mathrm{~mm}$ ). The test is repeated three times with the same reinforcement type and an arithmetic value is calculated. The strength values should not vary by more than $20 \%$ from the average value.

\section{2 ČSN 731333 (testing the bond-strength of pre- stressing reinforcement in concrete $)^{42}$}

This standard can be used for testing the bondstrength of prestressing reinforcement with common compacted or compacted light concrete from an artificial porous aggregate. This test is used to assess the bond- 
strength of the prestressing reinforcement in prestressed concrete. On the other hand, this standard cannot be used for assessing the effect of a construction loading on the strength of a bond of a prestressed reinforcement with the concrete (e.g., dynamically loaded constructions). It is important that this standard considers the mechanical bond between a prestressed reinforcement and the modified surface (imprints, ribs, corrugation, etc.) to be the deciding factor for anchoring the reinforcement in concrete.

Concrete hinders the movement of the reinforcement by pressing against its surface inhomegenities. Bonding is defined as a reliable and safe transfer of the prestressing force from a prestressing reinforcement to concrete. The initial shift of the prestressing reinforcement is defined by the standard as a "slip".

Similarly to the previous one, this standard also recommends two experimental set-ups: the testing of girders and of cubes. The testing of girders allows us to assess the bond-strength between a prestressing reinforcement and new-type surface modifications. The testing of cubes is viable for a study of the effects of various factors (surface modification of the reinforcement, composition, processing and treatment of concrete) on the bond-strength.

Three samples are tested after $28 \mathrm{~d}$ of the curing. The composition, the processing and curing process are precisely defined.

\subsubsection{Testing of the bond-strength of girders}

This standard evaluates the change in a prestressing-force value before and after a slip of the reinforcement inside a concrete sample. The slip length defining the bond-strength is defined as $0.001 \mathrm{~mm}$. The girder geometry is different from the girder in the ČSN 731328 standard. The cross-section of the girder is also rectangular; however, it only contains one or two tested prestressing reinforcement(s). The tail pieces of the reinforcement are anchored struts so that it cannot slip more than $\times 10^{-4}$ of its length between the anchoring points. The girder is usually equipped with detectors measuring the total longitudinal transformation (at least five on all the sides along the girder). The positions of dial deviation meters are similar to the ones defined in ČSN 731328.

The relative longitudinal girder transformation is the average value of all the values from the total longitudinal transformation of the opposite sides. The transformation magnitude versus time is plotted alongside the girder for every test stage. The changes in the prestressing force alongside the girder and the bond length are estimated from these plots. In this case, the bond length is considered to be the distance between the head of the reinforcement and the place where the transformation magnitude stops increasing. The reinforcement shift is the value from a dial deviation meter diminished by the value of the elastic shortening between the meter and the head of the girder.

The total value of the bond length is the average value calculated from the values taken up to six hours after introducing the prestressing load on both sides of all three girders (six values). The total value of the prestressing-reinforcement shift is calculated similarly, but from the reinforcement components (6-12 values). Individual values must not differ by more than $20 \%$ from the average value.

\subsubsection{Testing of the bond-strength of cubes}

During this test, a non-prestressed reinforcement is pulled out of a concrete cube. The set-up is similar to the one for the bond-strength test of the reinforcement and bars described in ČSN 73 1328. The bond-strength is calculated from the force necessary to pull the reinforcement out and from the shift of the other end of the reinforcement inside the concrete.

The cubes must be produced in such a way that the reinforcement rod is the cube's axis. The standard recommends the use of wooden trapezoidal laths to prevent the movement of the reinforcement. One lath is placed diagonally on the bottom of the mold, the other one is placed on top of it. The tailpieces of the reinforcement rod are placed in the holes of the laths.

The load of the prestressing reinforcement is measured by deviation with a $0.001 \mathrm{~mm}$ accuracy.

The force to pull the reinforcement out of the cube is increased in 8-12 steps with a short pause (30 s) between the steps. The force for each step is increased smoothly and slowly so that each step takes $20 \mathrm{~s}$.

The deviation is first measured before the loading, then a couple of steps before its maximum value and also after this value is exceeded. During the test, several values are monitored: the force during the first shift of the reinforcement inside the concrete sample $F_{\text {or }}$, the maximum force $F_{\max }$ and $F_{\text {lim }}$ which is the force acting when the reinforcement is being continuously pulled inside the sample without the need to increase this force. The stress of the bonding layer depends on $F_{\text {or }}, F_{\max }$ and $F_{\lim }$ and it is calculated with Equation (1), where $l$ is the

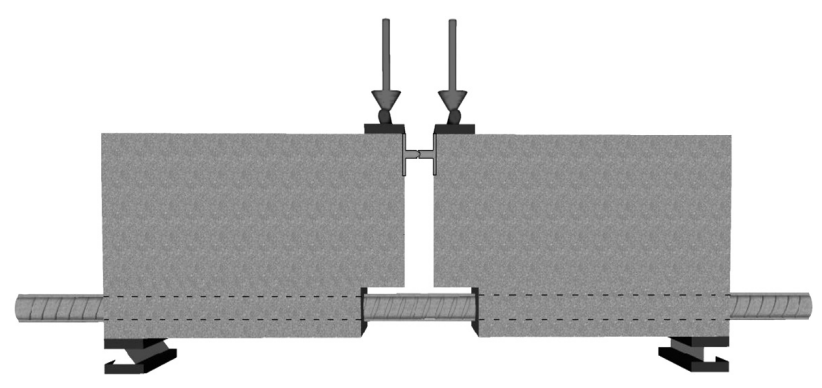

Figure 11: Schematics of a reinforced beam prepared for a beam test with arrows showing the applied forces and a connecting hinge according to RILEM RC5

Slika 11: Shematski prikaz ojačanega nosilca, pripravljenega za upogibni preizkus. Puščici kažeta uporabljeni sili in povezovalni tečaj, skladno z RILEM RC5 
length of the reinforcement set in the concrete and $a$ is the nominal perimeter length of the reinforcement:

$$
\tau_{x}=\frac{F_{x}}{l_{u}}
$$

The calculated stresses $\tau_{\mathrm{or}}, \tau_{\max }, \tau_{\lim }$ for the bonding layer are the average values of all the values of at least three measurements (three cube samples). Individual values must not vary by more than $30 \%$ from the average value.

\subsection{RC5 (bond test for reinforcement steel 1: beam test)}

RC5 is one of the basic RILEM recommendations dealing with another modification of the beam test. This procedure can be used to verify the bond-strength between common reinforcement and normal concrete, and also between prestressed constructions and concrete. An experimental set-up is depicted in Figure 11. Two separate concrete blocks are, at the bottom, connected by a reinforcement, whose bond-strength is to be measured. The reinforcement bar is again set into tubes to ensure its proper alignment and a precise bond length. The top parts of the blocks are connected by a separating hinge with a similar purpose as that of the interstices in the other set-ups. The hinge dimensions, the geometry of the supporting beams, the diameter of the reinforcement bars, the length and height of the concrete blocks and other parameters divide this test into two set-up groups types A and B. The inward shift of the reinforcement inside the block is measured on both sides. The locations of dial deviation meters are identical to the ones defined in ČSN 731328.

Similarly to the other standards, this recommendation also requires the use of non-corroded, properly degreased test samples. The surface modifications must not affect the geometry of the tested reinforcement bar. The standard defines the concrete composition (aggregate and gravel) in terms of a viable granulometry; the water content is strictly defined. Again, the compressive strength of the cubes is verified.

The bond-strength is measured after a $28 \mathrm{~d}$ curing in precisely defined conditions. After setting the test beam on a mobile ball or triangle support, a force is applied to the top part of the girder, symmetrically to both blocks. The force is applied continuously so that the next-step magnitude of the force is reached in up to $30 \mathrm{~s}$. After reaching the desired value, the applied force is held at that value for $120 \mathrm{~s}$. The shift of the bar towards the inside of the block is measured (an accuracy of 0.001 $\mathrm{mm}$ ); in addition, a measurement is taken for each step. The test continues until exceeding the bond-strength between the concrete and the reinforcement. ${ }^{43}$

\subsection{RC6 (bond test for reinforcement steel 2: pull-out test)}

The RILEM recommendation also provides an alternative "pull-out test" described in the ĆSN standards. A non-prestressed steel reinforcement with a minimum of $10 \mathrm{~mm}$ in diameter is recommended for a bond-strength measurement using this method. This test is recommended for the bond-strength testing of the reinforcements with different types of surface geometry. Considering the statistical evaluation, a minimum of 5 parallel samples is recommended. It is also recommended to set the reinforcement in a cubic concrete block. Again, the shift of the reinforcement towards the inside of the block is measured by a suitable deviation meter placed on the top part of the non-stressed reinforcement. The bond length of the reinforcement and the dimensions of the cube are chosen in such a way that they are proportional to the ratio between the bond length and the reinforcement-bar diameter. The reinforcement bar is, again, precisely inserted in a plastic tube which is suitably protected against the fresh-concrete contamination. The standard defines the preparation process and the composition of the concrete, its processing during the curing and the verification of its cubic compressive strength. The testing continues until a complete loss of the cohesion between the concrete and the reinforcement takes place. The result of this test is a loading curve $F=f(\Delta l)$. The loading force must be, similarly to the beam test (RC5), proportional to the diameter of the reinforcement bar and it must be continually increased (the rate of the increase must be steady).

The most important result of this experiment is the stress determined for the bonding layer, calculated from the loading force after the $28 \mathrm{~d}$ curing of the concrete. ${ }^{44}$

\section{CONCLUSION}

A good bond-strength between any reinforcement type and concrete is one of the main prerequisites for a reliable static function of steel-concrete constructions. The bond-strength is affected by many factors: the adhesive forces between concrete and reinforcement, the friction forces caused by the surface inhomogeneities of the flat parts of the reinforcement, the surface geometry (ribs, imprints and corrugations), the composition and mechanical properties of the used concrete, its processing, curing time and also the position of the reinforcement in the concrete.

To make a valid generalization about the effect of the corrosion of hot-dip galvanized steel or the constriction of epoxy coating, it is necessary to use the methods that minimize the effect of the concrete's mechanical properties on the measured bond-strength. The only suitable method is the pull-out test (the bond-strength test of bars and cubes). A very important requirement of this test is that the reinforcement must be placed along the longitudinal axis of the concrete sample so that the pulled-out 
reinforcement bar does not generate pressure forces. This can be achieved by using the tubes set in the concrete the reinforcement rod is inserted in these tubes and a proper alignment is ensured, unlike when using anchoring agents which are not part of the mold.

\section{Acknowledgement}

This work was accomplished with the financial support from Specific University Research (MSMT No. 20/2014), the Grant Agency of the Czech Republic, reg. number 14-20856S and the Technological Agency of the Czech Republic, TA02030164.

\section{REFERENCES}

${ }^{1}$ M. Collepardi, Moderní beton, ČKAIT, Praha 2009

${ }^{2}$ P. Pokorný, The influence of galvanized steel on bond strength with concrete, 56 (2012) 4, 119-135, doi: 10.2478/v10227-011-0020-9

${ }^{3}$ P. Novák, Z. Dong, L. Joska, Koroze ocelové výztuže v betonu, Koroze a ochrana materiálu, 40 (1996), 2-7

${ }^{4}$ A. R. Boğa, I. B. Topçu, M. Öztürk, Effect of fly-ash amount and cement type on the corrosion performance of the steel embedded in concrete, Mater. Tehnol., 46 (2012) 5, 511-518

${ }^{5}$ L. Bertolini, B. Elsner, P. Pedeferri, R. Polder, Corrosion of Steel in Concrete (Prevention, Diagnosis, Repair), Wiley-VCH, Weinheim 2004

${ }^{6} \mathrm{H}$. Böhni, Corrosion in reinforced concrete structures, WP, Cornwall 2005

${ }^{7}$ S. M. Alvarez, A. Bautista, F. Valesco, Influence of process parameters on the corrosion resistance of corrugated austenitic and duplex stainless steels, Mater. Tehnol., 47 (2013) 3, 317-321

${ }^{8}$ M. Kouřil, J. Stoulil, J. Bystrianský, R. Malá, P. Novák, Korozivzdorné oceli pro výztuže betonu, Koroze a ochrana materiálu, 46 (2002), 62-67

${ }^{9}$ M. Kouřil, P. Novák, M. Bojko, Threshold chloride concentration for stainless steels activation in concrete pore solution, Cement and Concrete Research, 40 (2010), 431-436, doi:10.1016/j.cemconres. 2009.11.005

${ }^{10}$ P. Aitcin, Vysokohodnotný beton, ČKAIT, Praha 2005

${ }^{11}$ F. Škvára, Technologie anorganických pojiv II., VŠCHT Praha, Praha 1995

${ }^{12}$ J. Procházka, P. Štěpánek, J. Krátký, A. Kohoutková, J. Vašková, Navrhování betonových konstrukcí 1 - Prvky z prostého železového betonu, CBS, Praha 2007

${ }^{13}$ http://www.tekna.no/ikbViewer/Content/225411/F40\%20-\%20 Sistonen\%20-\%202005-09-02\%20FINAL.pdf, 2. 6. 2012

${ }^{14}$ P. Pytlík, Technologie betonu, VUT Brno, Brno 2000

${ }^{15}$ ČSN EN 1992 -1 -1: Navrhování betonových konstrukcí - Část 1. 1.: Obecná pravidla a pravidla pro pozemní stavby (leden 2006)

${ }^{16}$ ČSN EN ISO 15630-1: Ocel pro výztuž a předpínání do betonuZkušební metody-Č́st 1: Tyče, válcovaný drát a drát pro výztuž do betonu (květen 2011)

${ }^{17}$ M. Kouřil, Š. Krtička, P. Novák, Soudržnost zinkované oceli s betonem, Koroze a ochrana materiálu, 51 (2007), 80-83

${ }^{18} \mathrm{~S}$. R. Yeomans, Galvanized steel reinforcement in concrete, Elsevier, Canberra 2004

${ }^{19}$ K. Wienerová, M. Kouřil, J. Stoulil, Koroze a ochrana zinkované oceli v betonu, Koroze a ochrana materiálu, 54 (2010), 148-154

${ }^{20}$ A. Bautista, J. A. Gonzales, Analysis of the protective efficiency of galvanizing against corrosion of reinforcements embedded in chloride contaminated concrete, Cement and Concrete Research, 26 (1996), 215-224, doi:10.1016/0008-8846(95)00215-4
${ }^{21}$ O. Kayali, S. R. Yeomans, Bond of ribbed galvanized reinforcing steel in concrete, Cement \& Concrete Composites, 22 (2000), 459-467, doi:10.1016/S0958-9465(00)00049-4

${ }^{22}$ O. Kayali, S. R. Yeomans, Bond and slip of coated reinforcement in concrete, Construction and Building Materials, 9 (1995), 219-226, doi:10.1016/0950-0618(95)00024-A

${ }^{23}$ A. Macías, C. Andrade, Corrosion of galvanized steel in dilute $\mathrm{Ca}(\mathrm{OH}) 2$ solutions ( $\mathrm{pH}$ 11.1-12.6), British Corrosion Journal, 22 (1987), 162-171, doi:10.1179/000705987798271505

${ }^{24}$ A. Macías, C. Andrade, Corrosion of galvanized steel reinforcements in alkaline solutions, Part 1: Electrochemical results, British Corrosion Journal, 22 (1987), 113-118, doi:10.1179/000705987798271631

${ }^{25}$ A. Macías, C. Andrade, Corrosion of galvanized steel reinforcements in alkaline solutions, Part 2: SEM study and identification of corrosion products, British Corrosion Journal, 22 (1987), 119-129, doi:10.1179/000705987798271749

${ }^{26}$ C. Andrade, J. D. Holst, U. Nürnberger, J. D. Whiteley, N. Woodman, Protection System for Reinforcement (Chapter 2 - Hot dip galvanizing). CEB - Bulletin D’Information, No. 211, Lousanne 1992

${ }^{27}$ A. Macías, C. Andrade, Corrosion rate of galvanized steel immersed in saturated solutions of $\mathrm{Ca}(\mathrm{OH}) 2$ in the $\mathrm{pH}$ range $12-13.8$, British Corrosion Journal, 18 (1983), 82-87, doi:10.1179/000705983798 273912

${ }^{28}$ M. T. Blanco, A. Macías, C. Andrade, SEM study of the corrosion products of galvanized reinforcements immersed in solutions in the pH range 12.6-13.6, British Corrosion Journal, 19 (1984), 41-48, doi:10.1179/000705984798273524

${ }^{29}$ A. Macías, C. Andrade, Galvanized steel behaviour in $\mathrm{Ca}(\mathrm{OH}) 2$ saturated solutions containing SO42- ions, Cement and Concrete Research, 17 (1987), 307-316, doi:10.1016/0008-8846(87)90113-X

${ }^{30} \mathrm{P}$. Rovnaníková, Problémy spojené s použitím pozinkované výztuže do betonu, Koroze a ochrana materiálu, 46 (2002), 104-107

${ }^{31}$ I. F. Olmo, E. Chacon, A. Irabien, Influence of lead, zinc, iron (III) and chromium (III) oxides on the setting time and strength development of Portland cement, Cement and Concrete Research, 31 (2001), 1213-1219

${ }^{32}$ C. Tashiro, H. Takahashi, M. Kanaya, I. Hirakida, R. Yoshida, Hardening property of cement mortar adding heavy metal compound and solubility of heavy metal from hardened mortar, Cement and Concrete Research, 7 (1977), 283-290, doi:10.1016/0008-8846(77) 90090-4

${ }^{33}$ A. Maldonado, O. Quiroz-Zavala, L. Diaz-Ballote, Bond between galvanized steel and concrete prepared with limestone aggregates, Anticorrosion Methods and Materials, 57 (2010), 305-313, doi:10.1108/00035591011087163

${ }^{34} \mathrm{Ch}$. Tashiro, S. Tatibana, Bond strength between C3S paste and iron, cooper or zinc wire and microstructure of interface, Cement and Concrete Research, 13 (1983), 377-382, doi:10.1016/0008-8846(83) 90037-6

${ }^{35}$ M. Bojko, Dizertační práce, VŠCHT Praha, Praha 2007

${ }^{36}$ A. R. Cusens, Z. Yu, Pullout tests of epoxy-coated reinforcement in concrete, Cement and Concrete Composites, 14 (1992), 269-276, doi:10.1016/0958-9465(92)90025-Q

${ }^{37}$ K. Kobayashi, K. Takewaka, Experimental studies on epoxy coated reinforcing steel for corrosion protection, The International Journal of Cement Composites and Lightweight Concrete, 6 (1984), 99-116, doi:10.1016/0262-5075(84)90039-3

${ }^{38}$ J. J. Assaad, C. A. Issa, Bond strength of epoxy coated bars in underwater concrete, Construction and Building Materials, 30 (2011), 667-674, doi:10.1016/j.conbuildmat.2011.12.047

${ }^{39}$ M. M. El-Hawary, Evaluation of bond strength of epoxy-coated bars in concrete exposed to marine environment, Construction and Building Materials, 13 (1999), 357-362, doi:10.1016/S0950-0618(99) 00042-2 
P. POKORNÝ et al.: PROBLEMS AND NORMATIVE EVALUATION OF BOND-STRENGTH TESTS ...

${ }^{40}$ R. Swamy, S. Koyama, Epoxy coated rebars the panacea for steel corrosion in concrete, Construction and Building Materials, 3 (1989), 86-91, doi:10.1016/S0950-0618(89)80006-6

${ }^{41}$ ČSN 73 1328: Stanovení soudržnosti oceli s betonem, 1971

${ }^{42}$ ČSN 73 1333: Zkoušení soudržnosti předpínací výztuže s betonem, 1990

${ }^{43}$ Technical Recommendations for the Testing and Use of Construction Materials (RILEM) RC5: Bond test for reinforcement steel - 1 . Beam test, 1982

${ }^{44}$ Technical Recommendations for the Testing and Use of Construction Materials (RILEM) RC6: Bond test for reinforcement steel -2 . Pull-out test, 1983 